\title{
There's Probably a Blackout in Your Television Future: Tracking New Carriage Negotiation Strategies Between Video Content Programmers and Distributors
}

\author{
Rob Frieden, ${ }^{*}$ Krishna Jayakar, ${ }^{* *}$ and Eun-A Park***
}

\begin{abstract}
Video programmers and the satellite and cable operators who distribute their content execute contracts for the mutually profitable offering of services to consumers. However, when programmers and distributors fail to reach closure on new terms and conditions before the end date of an existing agreement, service interruptions ("blackouts") occur. Video consumers resent having to pay sizable monthly subscriptions for content they temporarily cannot view, and both programmers and distributors risk financial injury.

Recognizing the mutual harm to all parties, video programmers and so-called Multichannel Video Programming Distributors ("MVPDs") usually limit the frequency and duration of blackouts. Heretofore, MVPDs have been able to pass on to subscribers higher programming costs through increased monthly rates without significant declines in subscribership. However, the marketplace for video programming has experienced significant change in recent years, calling into question the continuing ability of MVPDs to raise rates annually at percentages well above measures of general inflation. Additionally, MVPDs have experienced unprecedented declines in subscribership and encountered consumer resentment at having to pay rates, often in excess of $\$ 100$ monthly, for programming tiers containing dozens of channels, many of which few subscribers have an interest in viewing.

Through cord cutting and cord shaving, increasing numbers of video consumers have abandoned an MVPD subscription or downgraded to a less expensive service tier to incur lower monthly rates. Video consumers also have shown greater interest in so-called nonlinear content, available as downloadable files and streaming on demand from new online services, such as Amazon Prime, Hulu, and Netflix, in lieu

* Pioneers Chair and Professor of Telecommunications and Law, Penn State University. Email: rmf5@psu.edu.

** Professor, Penn State University. Email: kpj1@psu.edu.

*** Associate Professor, Western Colorado University. Email: eup112@gmail.com.

(C) 2020 Rob Frieden, Krishna Jayakar, and Eun-A Park. This is an open access article distributed under the terms of the Creative Commons Attribution License, which permits unrestricted use, distribution, and reproduction, provided the original authors and source are credited.
\end{abstract}


of conventional live, linear content transmitted by television broadcasters and MVPDs. The marketplace success of nonlinear video content providers demonstrates the growing willingness of consumers to use broadband networks for over-the-top ("OTT") access to alternative and competitive sources.

This Article identifies significant changes in the video marketplace that will trigger more frequent and longer blackouts. The Article will explain how marketplace changes impact the three major sources of video content that MVPDs and broadband networks deliver: (1) broadcast television channels; (2) video content targeted for MVPD subscribers, such as that on CNN, ESPN, and HBO; and (3) video, offered on both a linear and nonlinear basis, by new OTT ventures.

For broadcast television, this Article shows how current marketplace conditions challenge the ongoing viability of a legislatively crafted compromise that accords broadcasters the option of electing mandatory carriage of their signal by MVPDs (the "must-carry" requirement) in lieu of contractual "retransmission consent" negotiations. Broadcasters secure guaranteed carriage via MVPDs, and MVPDs benefit by the conferral of a low-cost copyright license to use broadcasters' content. For competing nonbroadcast video content, MVPDs and the manufacturers of devices, such as Roku, which transfer broadband video content to television sets via broadband networks, negotiate both copyright licenses and delivery rights directly with video programmers. This group also faces market volatility due to changes in consumer preferences and the growing array of video content options available.

The Article seeks to answer whether video programmers or MVPDs have overestimated their own negotiating leverage and, in turn, their ability to secure favorable contractual terms and conditions. Broadcasters historically appear to have greater leverage, because they have exclusive control over live, "must-see," linear content, such as sporting events. This advantage has motivated most broadcasters to eschew the must-carry option and elect retransmission consent negotiations. The Article suggests that a significant increase in blackouts has resulted from reduced opportunities for MVPDs to raise subscription rates without triggering substantial increases in subscriber migration to other broadband-delivered program options.

The Article notes that vertically and horizontally integrated MVPDs, such as AT\&T and Comcast, are better situated to tolerate more frequent and lengthy blackouts. These companies can offset the adverse financial impact of MVPD subscriber churn with blackout-free alternatives, increased subscribership of their broadband services and unregulated bundling of services and content for subscribers willing to upgrade and pay a higher monthly fee. The Article closely examines a recent antitrust enforcement case that approved AT\&T's acquisition of Time Warner, with an eye toward determining whether reviewing courts understood shifting marketplace conditions that affect the likelihood for more and longer blackouts.

The Article concludes that in the AT\&T case, both the district and appellate courts woefully underappreciated the ability of this widely diversified venture to trigger and tolerate more blackouts in its capacity as an MVPD and broadband access provider, separate and apart from its capacity as the new owner of Time Warner's "must-see" $\mathrm{CNN}$ and HBO content. The courts concluded that AT\&T, having largely abandoned its leverage over access to the Time Warner video content, lacked the ability to 
trigger blackouts. The courts emphasized the long-term carriage agreements Time Warner had previously negotiated with unaffiliated MVPDs and AT\&T's offer to maintain content access during arbitration of disputes occurring for seven years after merger approval. The courts failed to recognize the significant harm AT\&T, in its capacity as a major national MVPD, could inflict on competition and consumers by increasing its use of blackouts for negotiating leverage.

\section{TABLE OF CONTENTS}

Introduction. 489

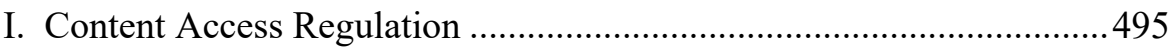

II. Balancing First Amendment and Public Policy Goals ...................... 498

III. Why Recent Retransmission Consent Negotiations Trigger More

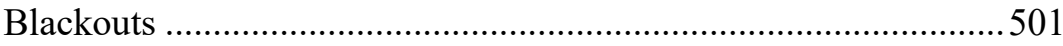

IV. Blackouts as Strategic Leverage in Multiple Scenarios ......................505

V. Outdated Assumptions About Blackouts in Judicial Treatment of the

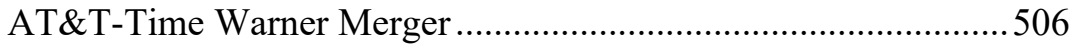

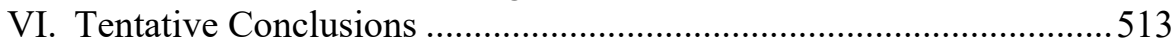

\section{INTRODUCTION}

One can consider the video marketplace as a "food chain" of vertically integrated segments, often served by different ventures. At the top, video programmers create content. This content eventually reaches consumers through intermediaries that package and physically deliver it via satellite, cable television, or a broadband distribution network. A single venture, such as AT\&T or Comcast, can vertically integrate throughout the food chain by creating, packaging, and delivering content. The significant increase in mergers and acquisitions achieving vertical integration shows that well-funded companies recognize the potential for efficiency and revenue enhancement offered by this business strategy; a single venture can serve as a "onestop shop" if it has the scale and financial resources to participate in all levels of the market. ${ }^{1}$

Ventures also can integrate horizontally by offering multiple products within the same market segment. The Federal Communications Commission ("FCC") uses the term Multichannel Video Programming Distributor ("MVPD") to identify companies that deliver video content to consumers via terrestrial and satellite transmission. AT\&T fits this definition in its capacity as a distributor of video channels via satellite (DirecTV) and wire (U-verse). This company and Comcast offer both wired and wireless broadband services that provide access to video content provided by their affiliated pay television networks and others.

1. For background information on the mergers and acquisitions of Federal Communications Commission licenses, see Mergers and Acquisitions, FED. COMM. CoMmission, https://perma.cc/F9JXHNHR (last visited Feb. 17, 2020). 
Before this onset of consolidation and concentration, ventures typically served a single market segment. Hollywood content creators offered product to unaffiliated syndicators and packagers, such as broadcast and cable television networks, who in turn negotiated with satellite and cable television distributors for the so-called "lastmile" delivery of content to subscribers.

Both video programmers and distributors incur ever-higher costs to create and distribute video content, particularly "must-see" sporting events. Carriage negotiations have become increasingly contentious, because neither party wants to bear a disproportionate share of increasing costs. Both parties may miscalculate the value of their contribution in the mutually beneficial delivery of content to consumers. When either party refuses to accept contract renewal terms and conditions, a content blackout occurs, depriving cable and satellite television subscribers of access to local broadcast television stations, pay television channels, or both, until a new contract for carriage comes into force. ${ }^{2}$ Recently, blackouts have occurred more often and for longer durations. Even though blackouts cause selfinflicted financial harm to both video programmers and distributors, while universally frustrating subscribers, these contentious and protracted negotiations have only become more frequent. ${ }^{3}$ This Article explains why. ${ }^{4}$

The increase in blackouts results from changes in the marketplace for video programming, including a proliferation of new video content access options, including on-demand access to content at rates far below those charged by incumbent ventures. The onset of expanded consumer access options and a growing intolerance for costly subscriptions to a large bundle of channels, not all of which a customer cares to watch, have a direct and significant impact on the negotiation strategies of both video programmers and distributors. For programmers, production costs have significantly increased to create content. In particular, sports programming costs have risen for broadcast and pay television programmers. ${ }^{5}$ Contributing factors

2. The Communications Act of 1934,47 U.S.C. $\S 1$ et seq., requires television stations to elect mandatory carriage of their signals by cable and satellite television operators at no additional compensation above a fee paid for a compulsory copyright license, or to negotiate payment for their "retransmission consent." Per 47 U.S.C. § 325(b), "[n]o cable system or other multichannel video programming distributor shall retransmit the signal of a broadcasting station, or any part thereof, except with the express authority of the originating station. ..."; moreover, "money or other consideration is generally exchanged between the parties in these private negotiations." Retransmission Consent, FED. Comm. Commission, https://perma.cc/ZDF9-SHVJ (last visited Feb. 17, 2020). If the parties do not produce an agreement in time, a blackout occurs until such time as the parties reach a new agreement.

3. The American Television Alliance, a trade association mostly funded by MVPDs, reports that 230 blackouts of local broadcast television stations occurred from January 1, 2019 to July 24, 2019, sixtyfive more than occurred during all of 2018. Press Release, Am. Television All., Broadcasters Are To Blame for Skyrocketing Retrans Fees and Record Number of TV Blackouts, Says ATVA (July 24, 2019), https://perma.cc/TWP2-FZBC.

4. Although this Article focuses on blackouts of local broadcast television stations, blackouts are also occurring in the pay television marketplace. See Mike Farrell, DirecTV Braces for Disney Blackout, MUlTiChANNEL NeWS (Sept. 10, 2019), https://perma.cc/LRY2-GMS6.

5. See Joan Engebretson, Report: Sports Programming Costs Average $\$ 18.55$ Per User or $22.1 \%$ of ARPU, TELECOMPETITOR (Apr. 26, 2019), https://perma.cc/V4KD-PGCH. These costs may be passed on to consumers, for whom sports programming accounts for a significant proportion of their cable bill. See Josh Mathews, Sports Broadcasting Blackouts: A Harbinger of Change in a Rapidly Evolving Media 
include the decision by more collegiate athletic conferences to create a network for packaging sports programming, and professional sports teams incurring ever-higher player salary costs. ${ }^{6}$

Competition for talent and for video content distribution rights has increased significantly with market entry by Amazon Prime, Hulu, Netflix, YouTube, and others. They offer on-demand, "nonlinear" content, available as a downloadable file or as a stream of packets delivered through a high-speed broadband network connection and augmented, in some cases, with live "linear" content, including simulcasts of broadcast networks. ${ }^{7}$ Even as video programming has diversified, most consumers still want access to both incumbent broadcast networks and pay channels, particularly when they offer live news coverage and sporting events. ${ }^{8}$ Although consumers have shown continued interest in some broadcast content, their willingness to forgo access to it and their dissatisfaction with having to subscribe to a large bundle of channels have led to a more unpredictable and volatile marketplace for both consumers and the ventures negotiating terms and conditions for content distribution.

Both local broadcast stations and premium content programmers have incurred higher costs at the same time as they confront declining viewership. ${ }^{9}$ With depressed ratings and a commensurate drop in advertising revenues, local broadcasters increasingly rely on retransmission compensation, the payments made by MVPDs for rights to deliver broadcast station content to subscribers. ${ }^{10}$ This arguably creates incentives for local broadcasters to drive a harder bargain.

Landscape?, 18 Hous. BUS. \& TAX L.J. 202, 203 (2018) (“Television consumers pay approximately 15\% of their cable bill for sports programming, regardless of [whether] they are consuming the product or not.").

6. See Steve Berkowitz, The SEC Has Record Revenue in 2018, but Big Ten Schools Rake in More Per-School Distribution, USA TODAY (Feb. 1, 2019), https://perma.cc/TBC3-T9U6 (noting new television agreements for the Big Ten Conference and increases in revenue for the SEC Conference from the SEC Network); John Ourand, The Escalation of Sports-Rights Fees Can Be Traced To a 2008 ESPN Deal, N.Y. Bus. J. (May 3, 2018), https://perma.cc/269P-RS6Q (noting the "ever-escalating state of sports rights since the 1970s").

7. "A linear channel is one that distributes programming at a scheduled time. Non-linear programming, such as video-on-demand ('VOD') and online video content, is available at a time of the viewer's choosing." Annual Assessment of Status of Competition in Mkt. for Delivery of Video Programming, 29 FCC Rcd. 1597, 1603, ๆ 15, n.23 (2014).

8. See Cal Keating, "Over the Top" or "Over the Heads" of Sports Broadcasting? Sports and Entertainment Content Licensing and Distribution in a New Era, 25 SPORTS L.J. 177, 181 (2018) (explaining that consumers can acquire a small bundle of channels, or even just one preferred channel, in lieu of a more costly programming tier containing a bundle of many channels); Kevin Draper, New Cable Network for A.C.C. Heightens Arms Race in College Sports, N.Y. Times (Aug. 22, 2019), https://perma.cc/YRG8-F2EA (acknowledging that video streaming will proliferate, but also noting that ESPN has nine channels of linear content).

9. See Stephen Battaglio, Network TV Viewing Is Down, but Strong Demand for Ads Is Expected To Boost Upfront Sales, L.A. TIMES (May 11, 2019), https://perma.cc/RFD5-UMGQ ("Nielsen data show prime-time television usage among 18 - to 49 -year-olds declined by $11 \%$ in the current TV season [2018], and $14 \%$ in the 18 -to-34 age group.").

10. See Sapna Maheshwari \& John Koblin, Why Traditional TV Is in Trouble, N.Y. TIMES (May 13, 2018), https://perma.cc/N9QB-BVMS (reporting a decline in television ratings and national television ad sales); Jon Lafayette, Study: TV Station Revenue to Reach \$32.8 Billion by 2020, BROAD. \& CABLE 
For pay television programmers, distribution rights always have constituted a key revenue stream; their business models have presumed a market structure where an intermediary - whether affiliated or not-operates a distribution platform for the last-mile delivery of content to consumers. While video programmers such as $\mathrm{HBO}$, ESPN, and even broadcast networks pursue direct delivery of content to consumers via broadband networks, most revenue still accrues from the distribution rights they negotiate with intermediary program distributors, such as cable and direct broadcast satellite operators. ${ }^{11}$

For content distributors, several new marketplace developments appear to contribute to the increased length and frequency of blackouts. Previously, MVPDs could expect to pass higher programming access costs on to satellite and cable subscribers, because few, if any, other options existed for accessing "must-see" television. Recently, however, consumers have become less tolerant of rising MVPD monthly subscription rates, the packaging of programming into large bundles of channels, and the unwillingness of MVPDs to offer discounts to reward subscriber loyalty. ${ }^{12}$ Broadband-delivered options have proliferated, offering consumers a better value proposition, even though they typically lack at least some of the content available from incumbent broadcast and pay television networks. Consumers appear increasingly willing to fully replace conventional, live, linear content, which is available on a specific MVPD channel at a designated time, with content that is available on demand. While consumers still have a clear preference for watching some types of programming on a linear basis, ${ }^{13}$ they also gladly avoid "appointment television" for content offered on a nonlinear basis - anytime, anywhere, via any device, and in multiple video presentation formats. ${ }^{14}$

(Mar. 16, 2018), https://perma.cc/MY3N-HG4F (reporting retransmission consent revenues represent nearly one-third of local broadcast stations' total income).

11. For background on how broadband delivery options impact the market for sports video, see David W. Sussman, Are Our Pastimes Past Their Time? How Will the Media Industry Disruption and Changes To the Legal Environment Affect the Sports Industry?, 67 SYRACUSE L. REV. 449 (2017); Matthew Edwards, Competitive Advantage: The Actions ESPN Must Take in Order To Maintain a Leadership Position in the Wake of Cable Un-Bundling, 46 Sw. L. REV. 197 (2016).

12. See James K. Willcox, Cable TV Fees Continue To Climb, Consumer RePs. (Feb. 21, 2019), https://perma.cc/8TA8-E669 (reporting annual increases in programming costs of eight to ten percent); Phillip Dampier, Altice Struggles with Video Programming Costs that Eat 67\% of Video Revenue, STOP THE CAP! (June 20, 2019), https://perma.cc/T7KD-KVY7 (discussing cable companies' unwillingness to offer deals due to shrinking profit margins).

13. "Traditional subscription television providers have come to rely most on live contentparticularly sports - to retain customers. Channels showing popular live sports have been relatively safe from this trend away from subscription television - sports content is generally considered 'appointment television,' which consumers insist on watching as it happens." James Rickard, Going Live: The Role of Automation in the Expeditious Removal of Online Content, 96 B.U. L. REV. 2171, 2175 (2016).

14. See Rob Frieden, Ex Ante Versus Ex Post Approaches To Network Neutrality: A Comparative Assessment, 30 BERKELEY TECH. L.J. 1561, 1606-07 (2015). ("Consumers have little patience for 'appointment television' that uses possibly exclusive, time-based windows in lieu of platforms for access at anytime, anywhere, via any device and in any delivery and presentation format. Consumers also evidence technology agnosticism in the sense that they appear to have little concern about the medium used to deliver content and to some extent the size and resolution of the presentation screen and degree of signal compression used.”); Commc’ns Marketplace Report, FCC 18-181, 2018 WL 6839365 at *22, 58 (rel. Dec. 26, 2018) ("MVPDs often distinguish themselves by offering varying amounts of VOD content, 
Cable and satellite television operators are facing declines in the total number of subscribers; existing subscribers are migrating to other providers, and the number of new subscribers has declined, particularly among young video consumers who have shown little interest in paying hefty monthly subscription rates for a large bundle of channels. ${ }^{15}$ Market analysts have coined terms to identify these defectors. "Cord nevers" refers to young video consumers who have never had to pay for a monthly video subscription and do not intend to start. This group is increasingly important to content providers, distributors, and advertisers, but does not appear to consider linear television more desirable or valuable than less expensive or advertiser-subsidized nonlinear content. "Cord cutters" abandon video programming service altogether, while retaining a broadband subscription. "Cord shavers" are the growing number of video consumers who downgrade to a less expensive service tier containing fewer channels.

A variety of video content sources, such as Amazon Prime, Apple, Crackle, Disney, Hulu, IMDb TV, Netflix, Pluto TV, Roku Channel, and YouTube, offer free streaming of video content or subscription rates well below what incumbent MVPDs charge. The marketplace success of these ventures shows a growing willingness of consumers to use their existing broadband network subscription for over-the-top ("OTT") access to alternative and competitive content sources. ${ }^{16}$

Such substantial changes in the video marketplace have affected the likelihood and duration of blackouts, even as courts fail to acknowledge or understand the impact of these fundamental changes when assessing whether and how mergers and acquisitions may harm consumers and competition. These marketplace changes also call into question whether there is still a need for legislation mandating that MVPDs provide local television broadcasters the opportunity to secure compulsory carriage of their signals. The public interest benefits from this "must-carry" obligation on MVPDs now appear debatable because major network affiliates are no longer electing this option, instead seeking monetary compensation from MVPDs for their retransmission consent for MVPD delivery of their signals to subscribers.

Critics of the status quo question the need for Federal Communications Commission ("FCC") regulatory intervention in the video marketplace. They

which gives subscribers access to a vast library of television shows and movies. This library of programming available 'on demand' offers subscribers another way to consume video programming besides the linear channels.").

15. See Todd Spangler, Traditional Pay-TV Operators Lost Record 6 Million Subscribers in 2019 as Cord-Cutting Picks Up Speed, VARIETY (Feb. 19, 2020), https://perma.cc/YBP4-PZPZ.

16. One source defines OTT as:

the practice of delivering video and other media over the internet, bypassing cable, broadband and satellite platforms. The term is usually applied to video-on-demand streaming services like Netflix, Disney+, Prime Video, Hulu and more. OTT content can be accessed through a computer, a mobile phone, or through a smart-TV or a conventional TV connected with an OTT streaming device, like Apple TV, Chromecast, Amazon Fire or even a video game console like a PlayStation or Xbox.

Carlos Alonso, What Is OTT (Over-The-Top)?, State of Digital Publishing (Nov. 20, 2019), https://perma.cc/52J8-JVYN. 
question the public interest merits of promoting local content sources and increasing diversity in programming and station ownership, in light of increased content access options and reduced reliance by broadcasters on their must-carry option. However, it appears that the FCC and courts overseeing antitrust complaints about proposed mergers have not considered how their decisions may increase the likelihood of blackouts.

This Article also will assess whether changes in the video marketplace have triggered new carriage negotiation strategies on both sides, and whether these already have triggered more blackouts. For local broadcasters, growing retransmission consent revenues represent an increasing percentage of total revenues, and thereby create incentives for tough bargaining. At the same time, MVPDs appear less able to pass on the higher programming costs demanded by both broadcasters and pay television networks, in light of growing subscriber defections ("churn") and competitive programming alternatives.

In response to volatile market conditions, many incumbent ventures see the benefit of vertical and horizontal integration through acquisitions. Economies of scale and scope can promote greater efficiency and profitability as ventures expand their reach within the ecosystem that connects content producers, packagers, and providers of last-mile delivery with consumers - via wireless terrestrial and satellite links, as well as copper and fiber optic cables. ${ }^{17}$ Instead of buying access to content and consumers, firms seek to control their destiny by acquiring market share in each market segment of the multi-tiered video "food chain."

Companies like AT\&T and Comcast seek to acquire companies that they previously paid for access to video content. Comcast, primarily a cable television MVPD, moved up the food chain by acquiring a major source of content: NBCUniversal. AT\&T executed a similar move by acquiring the source of $\mathrm{CNN}, \mathrm{HBO}$, and TNT content: Time Warner. Both companies successfully convinced the FCC and reviewing courts that these mergers would not harm competition and consumers, but instead might actually accrue positive outcomes for all stakeholders. In the most recent review of AT\&T's Time Warner acquisition, both the district and appellate courts considered and rejected several Department of Justice allegations of competitive and consumer harms, including the prospect for more blackouts. ${ }^{18}$

Both courts concentrated on whether AT\&T could trigger more blackouts by withholding or extorting high prices for its newly acquired "must-see" Time Warner content. The courts determined that AT\&T would have no greater incentives. Additionally, the courts noted the existence of long-term carriage agreements Time

17. One scholar explains economies of scope in this way:

A production technology has economies of scope if it is less expensive to produce certain goods together than separately. The production of wheat and straw, milk and cream, and wool and mutton are classic examples of such scope economies. By giving multiproduct firms a competitive cost advantage relative to single-product firms, economies of scope encourage firms to supply multiple products.

Ian Ayres, Rationalizing Antitrust Cluster Markets, 95 YALE L.J. 109, 114 (1985).

18. United States v. AT\&T, Inc., 310 F. Supp. 3d 161 (D.D.C. 2018), aff'd, 916 F.3d 1029 (D.C. Cir. 2019). 
Warner had previously negotiated with MVPDs, as well as the concessions made by AT\&T that it would refrain from triggering a blackout and instead rely on arbitration over the next seven years whenever a dispute arose regarding access to its video content.

The courts summarily dismissed the possibility that AT\&T would use blackouts in its capacity as a major wireless and terrestrial provider of MVPD and broadband services. Since it received approval to acquire Time Warner, AT\&T has triggered, or been the unwilling victim of, an unprecedented number of blackouts. ${ }^{19}$ Through diversification, primarily generated by mergers and acquisitions, AT\&T can tolerate possible losses in MVPD revenues and subscribers because of the potential for revenue increases accruing in the many other market segments AT\&T serves. For example, AT\&T might generate higher revenues during a blackout as video consumers migrate to one of AT\&T's MVPD options that might still offer must-see content unavailable from other MVPDs. Additionally, AT\&T might generate new subscriptions to its wired and wireless broadband services, which provide access to new OTT, nonlinear content, as well as higher revenues when existing MVPD and broadband service subscribers opt for more expensive service tiers, offering more channels of content and faster broadband transmission speed.

\section{CONTENT ACCESS REGULATION}

In the United States, cable television operators bear a statutory obligation to reserve up to one-third of their channel capacity for the compulsory carriage of significantly viewed local broadcast television stations. ${ }^{20}$ Congress subsequently addressed the issue of local broadcast television signal carriage by direct broadcast satellite ("DBS") operators, establishing a duty to offer all nearby signals when a DBS operator seeks to offer any broadcast television content to its existing inventory of pay television options. ${ }^{21}$

19. See DIRECTV, LLC, 34 FCC Rcd. 10367, 10368 (2019) (noting that AT\&T subscribers have experienced blackouts for approximately five months).

20. See Cable Television Consumer Protection and Competition Act of 1992, Pub. L. No. 102-385, 106 Stat. 1460. Specifically, the 1992 rules obligate cable systems with more than twelve channels of video programming to set aside up to one-third of their capacity for the retransmission of all commercial VHF and UHF stations broadcast in the local market; carry noncommercial stations (Public Broadcasting System affiliates); and carry up to two low-power TV stations broadcast locally where less than one-third of channel capacity was filled by commercial full-power stations. See Definition of Markets for Purposes of the Cable Television Mandatory Television Broadcast Signal Carriage Rules, 11 FCC Rcd. 6201 (1996) (defining local markets as Nielsen Media Research's designated market areas ("DMAs")).

21. A direct broadcast satellite ("DBS") operator's seeking to carry one local broadcast station in any market triggers an obligation to carry all other signals. See 47 U.S.C. § 338(a)(1) (2016). Congress imposed this "carry one carry all" requirement to ensure that DBS operators do not "cherry pick" and carry only network affiliates, an outcome it deemed detrimental to the viability of all broadcast television station operators. See H.R. REP. NO. 106-464, at 101 (1999) (explaining the legislative intent behind the requirement); Satellite Home Viewer Improvement Act of 1999, Pub. L. No. 106-113, 113 Stat. 1501, 1501A-526 to 1501A-545 (1999); Implementation of the Satellite Home Viewer Improvement Act of 1999, 15 FCC Rcd. 5445 (2000); Implementation of the Satellite Home Viewer Improvement Act of 1999: Enforcement Procedures for Retransmission Consent Violations, 15 FCC Rcd. 2522 (2000); Implementation of the Satellite Home Viewer Improvement Act of 1999: Broadcast Signal Carriage 
Cable operators objected to this obligation as both financially burdensome and an unconstitutional impediment to their First Amendment rights as aggregators and disseminators of content. ${ }^{22}$ While recognizing cable television operators' First Amendment speaker rights as aggregators and curators of content, the Supreme Court considered the "must-carry" obligation a lawful economic regulation, promoting access to diverse and local broadcast television content that, in turn, promotes a participatory democracy through widespread dissemination of news and public affairs programming. ${ }^{23}$

In 1992, Congress enacted a law codifying earlier FCC regulations that imposed a compulsory must-carry responsibility on cable television operators, based on the view that the public interest requires government intervention in the video marketplace to promote the commercial viability of local broadcast television. ${ }^{24}$ To offset the financial burden on cable television operators, the law prohibits television broadcasters electing the must-carry option from seeking financial compensation for MVPD retransmission of the "free-to-air" broadcast signal. Additionally, cable operators qualify for a compulsory and low-cost copyright license for access to broadcasters' content. ${ }^{25}$ Broadcasters not opting for the must-carry option negotiate retransmission consent payments from MVPDs for the right to deliver to subscribers the signal containing copyrighted content. ${ }^{26}$

Critics consider must-carry a "taking" of property and an intrusion into the speaker/programmer First Amendment rights of cable television operators. ${ }^{27}$

Issues, 16 FCC Rcd. 16544 (2001); KVMD Acquisition Corp. v. DirecTV, Inc., 16 FCC Rcd. 22040 (2001). See also Designated Mkt. Areas: Report to Cong. Pursuant to Section 109 of the STELA Reauthorization Act of 2014, 31 FCC Rcd. 5463 (2016) (explaining the DBS must-carry rules, including carriage of out-of-market broadcast television signals).

22. See Turner Broad. Sys., Inc. v. FCC, 512 U.S. 622, 637-41 (1994) (accepting that cable television operators have First Amendment speaker rights in their capacity as content packagers and distributors).

23. Turner Broad. Sys., Inc. v. FCC, 520 U.S. 180, 194 (1997) (explaining that broadcast television is "an essential part of the national discourse on subjects across the whole broad spectrum of speech, thought, and expression" and "Congress has an independent interest in preserving a multiplicity of broadcasters to ensure that all households have access to information and entertainment on an equal footing with those who subscribe to cable").

24. Cable Television Consumer Protection and Competition Act of 1992, Pub. L. No. 102-385, $\S 614,106$ Stat. 1460, 1471, codified at 47 U.S.C. $\$ 534$.

25. See 17 U.S.C. § 111(c) (2016); Competition, Rate Deregulation and the Comm'n's Policies Relating to the Provision of Cable Television Service, 5 FCC Rcd. 4962 (1990). The Satellite Home Viewer Act of 1988 created a compulsory license for satellite broadcasting similar in structure to the cable compulsory license. See Satellite Home Viewer Act of 1988, Pub. L. No. 100-667, 102 Stat. 3949 (codified as amended in scattered sections of 17 U.S.C.).

26. See Ryan Radia, Regulation Killed the Video Star: Toward a Freer Market in Broadcast Television, 67 FED. COMM. L.J. 235, 263 (2015). For background and history of the retransmission consent process, see Gregory J. Vogt, Does Retransmission Consent Need Fixing? (Or Do Consumers Need Help So They Can Watch the Super Bowl, World Series, and Academy Awards?), 22 CommLAW CONSPECTUS 108 (2013).

27. Opponents of government oversight argue that rules and regulations effectively deprive property owners of their lawful right to use and generate value from their property. See Nissa Laughner \& Justin Brown, Cable Operators' Fifth Amendment Claims Applied to Digital Must-Carry, 58 FED. COMM. L.J. 281 (2006). For discussion of the First Amendment rights of cable operators, see Turner Broad. Sys., Inc. v. FCC, 512 U.S. 622, 637, 662 (1994) ("There can be no disagreement on an initial 
However, the Supreme Court in 1997 deemed must-carry obligations a lawful, "content-neutral" regulation of cable television operators. ${ }^{28}$ While such regulation subordinates and conditions cable operators' constitutionally protected free speech rights, the Court ruled that the FCC could impose regulatory burdens on MVPDs because the rules did not target and promote specific types of speech. ${ }^{29}$

Must-carry promotes access to television broadcasters' signals, not any particular type of content available from broadcasters. The rule constitutes a content-neutral economic regulation serving three important governmental interests: (1) preserving the benefits of free, over-the-air, local broadcast television, (2) promoting the widespread dissemination of information from a multiplicity of sources, and (3) promoting fair competition in the market for television programming. ${ }^{30}$

Before receiving explicit statutory authority to regulate cable and satellite television, the FCC subjected these video distribution technologies to extensive "ancillary" regulation, based on the perceived need to avert the potential for adverse harm to the economic viability of local broadcast television. ${ }^{31}$ MVPDs have the capability to fragment local broadcasters' audiences and reduce revenues by offering consumers more video choices, such as distant broadcast signals and premium content available only to cable and satellite television subscribers. Must-carry

premise: Cable programmers and cable operators engage in and transmit speech, and they are entitled to the protection of the speech and press provisions of the First Amendment." (citing Leathers v. Medlock, 499 U.S. 439, 444 (1991))); id. at 663 ("[A]ssuring that the public has access to a multiplicity of information sources is a governmental purpose of the highest order, for it promotes values central to the First Amendment.").

28. Id. at 643 (holding that "the must-carry rules, on their face, impose burdens and confer benefits without reference to the content of speech").

29. See Turner Broad. Sys., Inc. v. FCC, 520 U.S. 180, 194 (1997) (recognizing the need to subordinate cable television operators' First Amendment freedom to ensure that broadcast television remains "an important source of information to many Americans," since "by tradition and use for decades now it has been an essential part of the national discourse on subjects across the whole broad spectrum of speech, thought, and expression”); Turner Broad. Sys., Inc. v. FCC, 512 U.S. 622, 663 (1994) (acknowledging that broadcast television, not cable television, "is demonstrably a principal source of information and entertainment for a great part of the Nation's population" (quoting United States v. Sw. Cable Co., 392 U.S. 157, 177 (1968))). See also Review of Comm'n's Regulations Governing Television Broad., 14 FCC Rcd. 12903, 12912 (1999) (finding that television is "the primary source of news and entertainment programming for Americans" and "play[s] a leading role in shaping democratic debate and cultural attitudes").

30. Turner Broad. Sys., 512 U.S. at 662.

31. See John Blevins, Jurisdiction as Competition Promotion: A Unified Theory of the FCC's Ancillary Jurisdiction, 36 Fla. St. U. L. ReV. 585 (2009); Cass R. Sunstein, The First Amendment in Cyberspace, 104 YaLe L.J. 1757, 1759 (1995); Mark A. Conrad, The Saga of Cable TV's 'Must-Carry' Rules: Will a New Phoenix Rise from the Constitutional Ashes?, 10 PACE L. REV. 9 (1990). While the FCC lacked explicit statutory authority, it established rules and regulations addressing the importing of distant broadcast television signals by cable television companies. The FCC based its jurisdiction over cable television operators on the grounds that their commercial activities could have an adverse financial impact on television broadcasters, over which the FCC has direct and explicit statutory authority. In United States v. Southwestern Cable Co., 392 U.S. 157 (1968), the Supreme Court affirmed the FCC's reference to Title I of the Communications Act of 1934, which confers general authority to regulate wire and radio services in the public interest. The Court determined that the FCC could establish limits on a San Diego cable television system's delivery of Los Angeles broadcast television stations in light of the potential for audience fragmentation and reduced revenues incurred by local stations. 
requirements ensure that video consumers still have the option of viewing local broadcast signals, even when subscribing to an MVPD. This requirement preempts a marketplace determination of whether consumers still want to view content available from local broadcasters. Legislative and regulatory decisionmaking results in part from the perceived need to safeguard market access opportunities for all television broadcasters - even though consumers might prefer news and live coverage of major events available from network-affiliated stations, but not necessarily what unaffiliated, minor stations offer.

Critics of must-carry requirements state that the primary beneficiaries are marginal television broadcasters, such as home shopping channels, while cable operators incur an unnecessary handicap in having to carry their signals. ${ }^{32}$ This argument had viability, if any, only during a brief time when cable operators had less channel capacity and must-carry duties crowded out possibly more desirable content. Now, cable and satellite MVPDs have expanded channel capacity, making it possible to satisfy must-carry obligations while also offering a wide array of nonbroadcast, pay television.

The must-carry requirement resulted from a legislative compromise designed to offset any financial burdens generated by compulsory signal carriage with a savings in copyright licensing costs. MVPDs qualify for a compulsory, low-cost copyright license for access to broadcast television content. Additionally, when cable and satellite operators comply with must-carry obligations, individual broadcasters cannot demand additional direct compensation for retransmission of their signal transmissions.

\section{BALANCING FIRST AMENDMENT AND PUBLIC POLICY GOALS}

In opting to impose must-carry responsibilities and other program access and carriage requirements on MVPDs, ${ }^{33}$ Congress has forced the FCC to make difficult

32. See Christopher S. Yoo, Rethinking the Commitment to Free, Local Television, 52 EMORY L.J. 1579 (2003); Thomas W. Hazlett, Digitizing “Must-Carry” Under Turner Broadcasting v. FCC (1997), 8 SUP. CT. ECON. REV. 141 (2000).

33. "Where Program Access protects MVPDs against potential abuses by programmers, Program Carriage protects programmers against certain potential abuses by MVPDs.” Jennifer Scullion, Program Access and Program Carriage: Nearly 25 Years In, Where Do the Fraternal Twins of Video Programming Distribution Stand? (pt. 2), ENT. \& SPORTS LAW., Summer 2016, at 3. See also Jennifer Scullion, Program Access and Program Carriage: Nearly 25 Years In, Where Do the Fraternal Twins of Video Programming Distribution Stand? (pt. 1), ENT. \& SPORTS LAW., Winter 2016, at 2 (2016). Section 628 of the Communications Act, codified at 47 U.S.C $\S 548$, makes it unlawful for a cable company to "engage in unfair methods of competition or unfair or deceptive acts or practices, the purpose or effect of which is to hinder significantly or to prevent any multichannel video programming distributor from providing satellite cable programming or satellite broadcast programming to subscribers or consumers." The FCC established rules that prohibit exclusive contracts between cable companies and company-owned cable channels. Section 616 of the Communications Act, codified at 47 U.S.C. § 536, prohibits MVPDs from "unreasonably restrain[ing] the ability of an unaffiliated video programming vendor to compete fairly by discriminating in video programming distribution on the basis of affiliation or nonaffiliation of vendors in the selection, terms, or conditions for carriage of video programming provided by such vendors." This section permits a cable network, unaffiliated with an MVPD, to challenge a vertically-integrated cable operator for giving preferential treatment to its own cable network. 
First Amendment balancing decisions between various creators, assemblers and distributors of content. ${ }^{34}$ This task becomes even more difficult with market entry by new OTT ventures, accessible via largely unregulated broadband conduits. ${ }^{35}$ The First Amendment appears to impose an absolute prohibition on governmental restrictions on speech, but in application many types of speech fall outside the prohibition, including obscenity, ${ }^{36}$ copyright infringement, ${ }^{37}$ speech that creates a clear and present danger of near-term lawlessness, ${ }^{38}$ and other speech subject to reasonable time, place, and manner restrictions. ${ }^{39}$ Likewise, video content triggers different levels of First Amendment protection depending on the medium used to deliver it.

34. Advocates for government intervention, notwithstanding the First Amendment, assert that the stakes are too high to rely on a volatile and easily distorted marketplace:

A vibrant marketplace of ideas is too important to our democracy. The media can inform the electorate, serve as a watchdog on corporate and political organizations, enhance market efficiency, and advance the discourse of public policy. One cannot rely on flawed laissez-faire beliefs that unregulated market forces will provide the efficient level of information. Nor can one assume that the current haphazard patchwork of media policies will remedy the current ailments in the media industry today or promote the unrestrained flow of information.

Maurice E. Stucke \& Allen P. Grunes, Toward a Better Competition Policy for the Media: The Challenge of Developing Antitrust Policies that Support the Media Sector's Unique Role in Our Democracy, 42 CONN. L. REV. 101, 146 (2009). Opponents consider regulation unnecessary in light of robust competition:

The logic behind the scarcity doctrine was never valid and was merely a thinly veiled political excuse to regulate communications while skirting the First Amendment. There is no basis for distinguishing media content by the roads it travels. Today that exercise has become a fool's errand. Is the New York Times transmitted via a Sprint 3G network to a Kindle deserving of the newspaper freedoms, or is the public interest dictated by frequency scarcity? The convergence of print and wireless makes the emptiness of the scarcity doctrine emptiness-squared.

Thomas W. Hazlet, Sarah Oh \& Drew Clark, The Overly Active Corpse of Red Lion, 9 Nw. J. TeCH. \& INTELL. PROP. 51, 94-95 (2010).

35. See Daniel A. Lyons, An Antitrust-Informed Approach to Regulating Internet Interconnection, 24 B.U. J. SCI. \& TECH. L. 229 (2018); William Lehr \& Douglas Sicker, Would You Like Your Internet With or Without Video?, 2017 U. ILL. J.L. TECH. \& POL'Y 73 (2017); Rob Frieden, The Rise of QuasiCommon Carriers and Conduit Convergence, 9 I/S: J. L. \& POL'Y FOR INFO. SOC'Y 471 (2014); Note, Enabling Television Competition in a Converged Market, 126 HARV. L. REV. 2083 (2013); Nick Gamse, The Indecency of Indecency: How Technology Affects the Constitutionality of Content-Based Broadcast Regulation, 22 FordHAM INTELL. PROP. MEDIA \& ENT. L.J. 287 (2012).

36. Miller v. California, 413 U.S. 15, 20 (1973) (finding no First Amendment protection for work, taken as a whole, that appeals to the prurient interest in sex; that portrays, in a patently offensive way, sexual conduct specifically defined by the applicable state law; and that, taken as a whole, does not have serious literary, artistic, political, or scientific value).

37. Roy Export Co. v. CBS, Inc., 672 F.2d 1095, 1099 (2d Cir. 1982) ("No circuit that has considered the question ... has ever held that the First Amendment provides a privilege in the copyright field distinct from the accommodation embodied in the 'fair use' doctrine."). See also Neil Weinstock Netanel, Locating Copyright Within the First Amendment Skein, 54 STAN. L. REV. 1 (2001).

38. See, e.g., Brandenburg v. Ohio, 395 U.S. 444, 447 (1969) (holding that prohibition of incitement requires finding a likelihood of imminent lawlessness).

39. See, e.g., Cox v. New Hampshire, 312 U.S. 569 (1941) (city control over streets includes time, place, and manner restrictions on parades and demonstrations). See also Susan H. Williams, Content Discrimination and the First Amendment, 139 U. PA. L. REV. 615 (Jan. 1991). 
The Supreme Court has interpreted the First Amendment differently depending on which aspect of free speech the Court examines. ${ }^{40}$ For example, the Court endorsed limitations on speaker rights in terms of time, place, and manner of speech when the government has a compelling justification and the imposed restrictions do not directly target a specific type of speech. ${ }^{41}$ To survive judicial review, laws must restrict speech as narrowly as possible to avoid any overbreadth that would potentially limit or constrain permissible speech. ${ }^{42}$

Cable and satellite television operators qualify for conditional First Amendment speaker freedoms when selecting which channels to include within their programming tiers. ${ }^{43}$ Accordingly, one could consider the must-carry requirement a direct content-based restriction, thereby obligating government to articulate a compelling justification for any restriction on video distributors' First Amendment rights. Courts have accepted as reasonable a government goal of promoting the economic viability of broadcast television, both in terms of guaranteeing access by the public without having to pay for a subscription and in terms of broadcasters' contribution to the national interest in having an informed and involved electorate. ${ }^{44}$

The nature and scope of judicial scrutiny applied to media speech depends on whether the restriction directly or indirectly affects content. The Supreme Court considered must-carry "content neutral," because the restriction on cable operators' speech applied to a type of signal that cable operators must deliver to subscribers and not to any type of specific content contained in that transmission. In other words, a must-carry requirement supports television broadcasters; it does not specifically favor any type of content produced and disseminated by television broadcasters. ${ }^{45}$

40. Compare Miami Herald Publ'g Co. v. Tornillo, 418 U.S. 241 (1974) (state law mandating right of reply to editorial deemed to violate newspaper publisher's First Amendment speaker rights) with Red Lion Broad. Co. v. FCC, 395 U.S. 367 (1969) (upholding FCC-mandated right of reply to broadcast's personal attack in light of listeners' greater First Amendment rights as compared to broadcasters'). See also Robert Frieden, The Impact of Next Generation Television on Consumers and the First Amendment, 24 Fordham Intell. Prop. Media \& ENT. L.J. 61 (2013); Christopher S. Yoo, The Rise and Demise of the Technology-Specific Approach to the First Amendment, 91 GEO. L.J. 245 (2003).

41. See generally Geoffrey R. Stone, Content-Neutral Restrictions, 54 U. CHI. L. REV. 46 (1987) (describing the Court's First Amendment jurisprudence).

42. United States v. O'Brien, 391 U.S. 367, 377 (1968) (deeming reasonably narrow a law punishing the destruction of government property when a Vietnam War protestor burned his draft card). See also Nancy J. Whitmor, The Evolution of the Intermediate Scrutiny Standard and the Rise of the Bottleneck "Rule" in the Turner Decisions, 8 COMM. L. \& POL'Y 25 (2003).

43. Turner Broad. Sys., Inc. v. FCC, 512 U.S. 622 (1994) (articulating First Amendment intermediate scrutiny standard allowing content-neutral regulation that can indirectly affect an entity's First Amendment rights only if the regulation furthers an important or substantial government interest and the restriction on speech is no greater than is essential to the furtherance of that interest); Cablevision Sys. Corp. v. FCC, 597 F.3d 1306 (D.C. Cir. 2010) (finding no First Amendment violation of cable operators' First Amendment speaker rights when the FCC extended for five years a statutory prohibition against exclusive contracts between cable operators and cable-affiliated programming networks).

44. See, e.g., Quincy Cable TV, Inc. v. FCC, 768 F.2d 1434, 1439 (D.C. Cir. 1985), cert. denied, 476 U.S. 1169 (1986) (defining must-carry requirements to include all commercial broadcast stations within a thirty-five mile radius of the community served by the cable system and other stations "significantly viewed" in the community).

45. See Marc Peritz, Turner Broadcasting v. FCC: A First Amendment Challenge To Cable Television Must-Carry Rules, 3 WM. \& MARY BILL RTS. J. 715 (1994). 
For restrictions on First Amendment freedom that do not directly impact or favor content, the Court uses an "intermediate scrutiny" standard to consider the reasonableness of the restriction and its specificity.

The Supreme Court first articulated the intermediate scrutiny standard when it determined that a Vietnam War protestor should face jail time for burning his draft card even though he sought to make a political statement. ${ }^{46}$ Because the government could articulate a reasonable justification for prohibiting draft card destruction (effective administration of the conscription process), the Supreme Court upheld a criminal conviction, despite the symbolic, political nature of an act protesting armed conflict.

\section{WHY RECENT RETRANSMISSION CONSENT NEGOTIATIONS TRIGGER MORE BLACKOUTS}

Blackouts have increased in number and duration in the last few years. ${ }^{47}$ Several factors contribute to this major consumer irritant, including greater reliance by television networks and broadcasters on the revenues generated from retransmission consent, higher programming costs, improved and more widely available broadband access, and a substantial increase in direct-to-consumer content options.

Prior to the onset of these changes, an entrenched legacy model maximized financial benefits for both video programmers and distributors. Programmers opted to rely solely on terrestrial and satellite MVPDs for content delivery. Such reliance made sense because technological alternatives to appointment television, such as ondemand access to nonlinear content via broadband links, had not reached a critical mass of affordability and widespread adoption. The parties could not easily and affordably eliminate their mutual reliance on each other. Most MVPDs had not yet vertically integrated by combining content distribution technology with content creation. Likewise, content creators had no viable means to eliminate the MVPD intermediary role by offering content directly to consumers.

Mutually beneficial reliance on what the other party had to offer made it possible for broadcast networks and their network affiliates to remain profitable and able to increase the cost of retransmission consent on a regular basis. MVPDs had no viable alternative to their reliance on incumbent content creators. Infrequent blackouts were quickly resolved, with the MVPD typically agreeing to pay higher compensation to content creators. The parties also might agree to reduced price increases for carriage of existing channels if the MVPD expanded network capacity and agreed to carry new affiliated channels, such as ESPN-2 and ESPN-3. These new affiliated channels were usually considered to offer somewhat less attractive content than the original, flagship channel, but were key to content creators' interest in expanding their "shelf space" on MVPD programming tiers.

46. United States v. O’Brien, 391 U.S. 367 (1968).

47. The American Television Alliance reported 165 broadcast television blackouts in 2018; 213 blackouts in 2017; 104 blackouts in 2016; 193 blackouts in 2015; 94 blackouts in 2014; 119 blackouts in 2013; 90 blackouts in 2012; 42 blackouts in 2011; and 8 blackouts in 2010. Press Release, Am. Television All., supra note 3. 
Additionally, MVPDs and nonbroadcast, pay television cable networks could execute similar, if more expensive, content distribution agreements because MVPDs had no viable content access alternatives. MVPDs could absorb higher content costs by increasing monthly subscriber rates and spreading higher programming costs over a large bundle of content in a programming tier combining high-demand, "must-see" channels with less desirable networks. The subscription cost for the so-called Enhanced Basic tier has increased well in excess of general inflation measures, but MVPDs could partially deflect that irritant by regularly expanding the number of channels. ${ }^{48}$ Absent technologies available to provide à la carte access to specific channels or any willingness by MVPDs to provide that option, the status quo remained entrenched.

The proliferation of broadband technologies and new, lower-cost OTT video options upset this equilibrium. ${ }^{49}$ Consumers adopted often unlawful, copyrightinfringing self-help opportunities to access premium content separate from the conventional MVPD distribution arrangement. Additionally, some content creators, independent from companies with MVPD or broadcast television ownership interests, started to explore "television everywhere" content access options via wired and wireless broadband technologies. MVPDs belatedly offered similar access options to subscribers, ostensibly as a convenience and value-enhancing proposition, but also to keep them from cutting the cord altogether. Most content creators supported this change to the status quo because they could contractually limit television-everywhere access to MVPD subscribers and require proof of an ongoing subscription in a firewall authentication process.

Consumers experienced a quandary: On one hand, they grew increasingly frustrated by regular MVPD subscription rate increases, particularly in light of the growing availability of new broadband technologies that could stream the same, or equally compelling, content. On the other hand, consumers have not lost their appetite for conventional, linear appointment television, particularly the news, sports, and live programming provided by the broadcast networks.

48. An FCC report illustrates this point:

Over the 12 months ending January 1, 2017, the average monthly price paid by subscribers who take only basic cable service grew by an average of $5.2 \%$, to $\$ 25.06$. The average price for expanded basic cable service (the next level of service above the basic tier) rose by $3.2 \%$ over the same one-year period to $\$ 75.21$. Over the five years ending January 1,2017 , the price of expanded basic service rose, on average, by $4.1 \%$ annually. Average price per channel (price divided by the number of channels offered with expanded basic service) fell by $10.1 \%$ to 49 cents per channel over the 12 months ending January 1, 2017. Over the last five years, price per channel has decreased, on average, by $0.8 \%$ annually. For comparison, the rate of general inflation measured by the Consumer Price Index (all items) rose by $2.5 \%$ over the 12 months ending January 1, 2017, and at an average annual rate of $1.4 \%$ over the last five years.

Communications Marketplace Report, 33 FCC Rcd. 12558, 12605 (2018) [hereinafter FCC 2018 Marketplace Report].

49. See, e.g., Henry H. Perritt, Jr., Keeping the Internet Invisible: Television Takes Over, $21 \mathrm{~J}$. TECH. L. \& POL'Y 121 (2017) (assessing the impact of video available primarily via broadband networks). 
Video consumer ambivalence appears to have intensified retransmission consent negotiations, as well as the likelihood of a blackout. ${ }^{50}$ Television broadcasters increasingly rely on retransmission consent revenues to offset both their programming costs and the compensation they owe their affiliated national broadcast networks:

Over the past nine months, cable operators and broadcasters have been at each other's throats more than ever, fueled by fears of greater regulation and a declining pay TV customer base. According to some analysts, as broadcasters have increasingly relied on retransmission-consent cash to prop up a shrinking ad business, many are digging in their heels not only for higher fees, but for guarantees they will be paid regardless of the impact of cord-cutting. ${ }^{51}$

Notwithstanding growing evidence of consumer intolerance for higher rates from MVPDs, reduced audience ratings and advertising revenues, and piracy, broadcast networks and their affiliated stations have persisted in demanding higher retransmission compensation. This strategy may reflect the perception of greater negotiating leverage available when operating in a highly concentrated market. ${ }^{52}$ Such consolidation may have emboldened the fewer remaining multiple station owners to leverage access to a national footprint in a single commercial negotiation with MVPDs. ${ }^{53}$ This development may explain why the FCC recently determined that Sinclair Broadcasting, a major network affiliate station owner, lacked good faith in negotiating retransmission consent agreements with AT\&T. ${ }^{54}$

Retransmission consent compensation paid to local broadcasters from MVPDs has increased significantly. ${ }^{55}$ In 2017, MVPDs paid local broadcast television

50. For example, both content creators and MVPDs sought to influence the court of public opinion with newspaper advertisements and social media. See, e.g., Sean Hollister, Roku Is Losing Fox Apps Just in Time for You To Miss the Super Bowl, Maybe, VERGE (Jan. 30, 2020), https://perma.cc/R9AJ-42GK.

51. Mike Farrell, Is the Retrans Cash Cow Running Low?, MulTiCHANnEL News (Oct. 7, 2019), https://perma.cc/ZZ4E-CEH7.

52. See Annual Assessment of the Status of Competition in the Mkt. for the Delivery of Video Programming, 32 FCC Rcd. 568, 600-01 (2017).

53. For example, MVPDs have asserted that mergers by two large broadcast station owners will adversely affect the balance of power in retransmission consent negotiations. See Tribune Media Co., 34 FCC Rcd. 8436, 8445 (2019) (granting transfer and assignment application). The FCC has dismissed such assertions as meritless:

[W] conclude that the petitioners' allegations regarding retransmission consent do not raise a substantial and material question of fact as to whether grant of the Applications would serve the public interest. As an initial matter, we conclude that, with our simultaneous approval of the proposed divestitures in this proceeding, described above, the transaction will not meaningfully change the bargaining leverage the Applicants currently possess in local markets. In particular, in those individual DMAs where Nexstar will acquire stations affiliated with one of the "Big Four" broadcast networks (ABC, CBS, NBC, or FOX) from Tribune, Nexstar will simply step into Tribune's shoes, with no change in local market concentration among Big Four affiliates, and the same will be true for any divestiture entity.

Id. at 8450 .

54. See supra note 19.

55. "Today, broadcast stations are turning increasingly to additional revenue sources, including retransmission consent fees from MVPDs and advertising sold on their websites." Farrell, supra note 51 
stations $\$ 9.3$ billion for consent to retransmit their content, representing thirty percent of the stations' total revenue. ${ }^{56}$ Ever-rising licensing costs for professional and collegiate sport broadcast rights are a key factor behind steep increases in retransmission consent compensation rates. ${ }^{57}$ Despite reduction in both broadcast television and MVPD viewership, ${ }^{58}$ live sports remains the most-watched programming category, still exceeding the audience ratings for pay television content. $^{59}$ Generating the largest audience provides one of the few remaining opportunities for both broadcasters and MVPDs to offer cost-efficient opportunities for mass market advertisers.

The financial stakes in retransmission consent negotiations between broadcasters and MVPDs have increased substantially, much like negotiations between other video content producers (such as pay television networks like ESPN) and distributors (such as OTT networks). Ironically, the proliferation of OTT alternatives may support a bolder negotiating posture for local broadcasters rather than push retransmission compensation rates downward. With a few exceptions, such as Hulu and YouTube $\mathrm{TV},{ }^{60}$ most new video programming distributors, transmitting via broadband networks, do not offer live, linear programming like that offered by local broadcasters. $^{61}$ With recent price hikes by OTT program distributors, which now offer larger bundles of channels instead of a "skinny bundle" of fewer channels, and decisions by many consumers to diversify content options by subscribing to multiple vendors, the total monthly cost of video access approaches what incumbent satellite and cable MVPDs charge. ${ }^{62}$ Broadcast television content remains on most

(reporting an estimate of $\$ 11.7$ billion in retransmission consent revenues for 2019 , a $10.8 \%$ increase over 2018).

56. FCC 2018 Marketplace Report, supra note 48, at 12616.

57. See The Rising Cost of Programming, ARMSTRONG CABLE, https://perma.cc/D2YA-CRAN (last visited Feb. 23, 2020).

58. See FCC 2018 Marketplace Report, supra note 48, at 12598 ("Collectively, MVPDs lost about 3.6 million video subscribers ... [in 2017]. Cable MVPDs lost 986,000 subscribers; DBS MVPDs lost 1,693,000 subscribers; and telephone company MVPDs lost 903,000 subscribers.”).

59. Nielsen Holdings reported the highest rated programs for 2018 were the NFL championship Super Bowl, on NBC, with 103.4 million viewers; the World Series professional baseball championship, comprising five games, on Fox, with 71.8 million viewers; the NBA professional basketball championship, comprising four games, on ABC, with 70.3 million viewers; the Winter Olympics opening ceremony, on NBC, with 27.8 million viewers; and the Stanley Cup professional hockey finals, comprising five matches, on NBC and the NBC Sports Network, with 24 million viewers. Reuben Gregg Brewer, Here Are the 5 Highest-Rated TV Events of 2018 and What They Mean for TV's Future, THE MOTLEY FOOL (Dec. 16, 2018), https://perma.cc/BBS8-MZ3S.

60. AT\&T, Dish Network, Hulu, and YouTube TV offer live broadcast network content. See, e.g., More Than Just Live TV, HuLU, https://perma.cc/MH59-VNSP (last visited Feb. 23, 2020); Jon Brodkin, Google Fiber Kills TV Service, Focuses on Broadband and YouTube TV, ARS TECHNICA (Feb. 5, 2020), https://perma.cc/4AL6-M6FQ.

61. Despite the success of Amazon Prime, Netflix, and Hulu, the vast majority of consumers continue to subscribe to cable, satellite, or telephone company MVPDs. Of the ninety-four million video subscribers in 2017, cable served 51.9 million, DBS served 31.5 million, and telephone companies served 10.6 million. FCC 2018 Marketplace Report, supra note 48, at 12598, fig.B-6. Virtual MVPDs, which provide similar programming via a broadband link, only had a total market share of 2.6 million subscribers, while Amazon Prime reached 11.8 million and Netflix 4.9 million. Id.

62. See, e.g., James K. Willcox, Netflix Price Hike Points to the Changing Math of Cord Cutting, CONSUMER REP. (Jan. 16, 2019), https://perma.cc/NZ3J-4H83; Mike Snider, Cord Cutter Déjà Vu: 
consumers' "must-have" lists, possibly bolstering broadcasters' retransmission consent negotiations despite the availability of premium nonlinear content from Netflix and others.

\section{BLACKOUTS AS STRATEGIC LEVERAGE IN MULTIPLE SCENARIOS}

As blackouts grow in number, so too do the scenarios in which a blackout provides negotiating leverage for both programmers and distributors, particularly for ventures like AT\&T and Comcast that operate in both market segments. Prior to the onset of widespread broadband access coupled with the diversification of content access options provided via video streaming, a single blackout strategy made sense to all parties: Avoid them whenever possible and resolve them quickly. The balance of power appeared to favor content creators, particularly broadcast networks, because MVPDs had no viable alternative to acquiring distribution rights to compelling, linear content.

Premium content carriage and broadcast signal retransmission content negotiations have become far more complex in light of crosscurrents in the video marketplace. Even though live, linear programming still represents one of the most sought-after types of content, consumers in growing numbers have shown a willingness to make do with less, or even no, access. Cord shavers and cord cutters have significantly increased in number. A smaller number of consumers appear satisfied with large bundles of linear content channels from MVPDs at rates well in excess of the costs of either subscribing to a skinny bundle of pay television channels or paying the subscription rates for nonlinear content offered by Amazon, Apple, CBS, Disney, Hulu, Netflix, and others. ${ }^{63}$

Simply put, programmers cannot now blithely assume that MVPDs will "blink first" and absorb, or easily pass on to subscribers, programming cost increases. As discussed in the next section, ventures like AT\&T, operating in several sectors of the video and broadband marketplace, are likely to have different levels of blackout tolerance depending on their ability to offset revenue losses from one market sector with revenue increases from others. It appears that rather than make blackout avoidance a priority, AT\&T now uses blackouts as leverage to extract concessions. The company has effective ways to reduce its exposure to potential financial losses from blackouts, while its negotiating partners may lack such safety valves.

Streaming Channels Are Looking More Like Those Hated Cable TV Bundles, USA TODAY (July 12, 2018), https://perma.cc/U385-7H9P.

63. Kelsey Sutton, Nearly 25\% of U.S. Households Will Be Cord-Cutters by 2022, According To EMarketer, ADWEEK (Aug. 6, 2019), https://perma.cc/7Q2A-8VAN; Adam Jacobson, Cord-Cutting 'At the Crossroads': A Dangerous MVPD Scenario, RADIO \& TELEVISION Bus. REP. (Mar. 13, 2019), https://perma.cc/CWK2-ZN3E (reporting forecasts of near-term $4.1 \%$ rate of MVPD subscribership decline moderating to $3 \%$ or increasing substantially to previously unthinkable levels). 


\section{OUTDATED ASSUMPTIONS ABOUT BLACKOUTS IN JUDICIAL TREATMENT OF THE AT\&T-TIME WARNER MERGER}

Both the district court's consideration of the Justice Department's 2018 antitrust challenge to AT\&T's $\$ 85$ billion acquisition of Time Warner and the appellate court's review made arguably faulty assumptions about the current video programming marketplace. ${ }^{64}$ At both levels, the courts accepted the conventional wisdom that vertical market acquisitions trigger little, if any, competitive and consumer harm because the two ventures did not previously compete in the same market segment. Additionally, the courts dismissed as implausible any scenario where AT\&T could achieve greater negotiating leverage through the prospect of more frequent and longer blackouts.

Both courts embraced video streaming competition as evidence that AT\&T would have little or no opportunity to benefit from a blackout, based on the assumption that consumers increasingly can find identical or alternative content elsewhere. ${ }^{65}$ The courts relied on flawed or erroneous assumptions about the video marketplace and the potential for vertical integration to harm competition and consumers. While emphasizing the implausibility of more blackouts triggered by a content-rich AT\&T, the courts failed to understand that the firm will have many opportunities for offering bundles of content, broadband access, and telephone services.

District Court Judge Richard J. Leon concluded that a content programmer such as AT\&T would rarely, if ever, financially gain by withholding content in order to extract higher prices from an MVPD competitor, even for highly desired, linear video content. ${ }^{66}$ He concluded that AT\&T's vertical integration into content ownership could not raise the cost of access to Time Warner content by MVPDs competing with AT\&T. Judge Leon did not address any scenario where AT\&T would engage in price discrimination as a content programmer not by seeking to charge higher rates to unaffiliated MVPDs, but by exploiting flexibility in packaging content, such as offering an HBO subscription as a "free" inducement for AT\&T wireless subscribers to migrate to a more expensive tier of service.

64. United States v. AT\&T, Inc. (AT\&T I), 310 F. Supp. 3d 161 (D.D.C. 2018), aff'd, 916 F.3d 1029 (D.C. Cir. 2019).

65. AT\&T I, $310 \mathrm{~F}$. Supp. at 196-97 (acknowledging the potential for MVPD subscribers to migrate to new OTT options such as Netflix); United States v. AT\&T, Inc. (AT\&T II), 916 F.3d 1029, 1046 (D.C. Cir. 2019) (recognizing the video industry is continually changing and experiencing increasing competition).

66. See $A T \& T I, 310$ F. Supp. at 200 ("Given that blackouts are negative events for both programmers and distributors, however, deals between programmers and distributors are invariably struck in order to avoid long-term blackouts."); id. at 214 ("[G]iven that a post-merger Turner, like a pre-merger Turner, would stand to suffer large losses in affiliate fee and advertising revenues in the event of a blackout - the record is barren of any contentions by the third-party competitors that they would actually give in to any price increases demanded by Turner as a result of its purported increase in post-merger leverage."). Judge Leon agreed with the defendant's assertion that no single programming network, or group thereof, is so essential that its absence would render the venture uncompetitive: "[B]ased on the evidence, I agree with defendants that Turner's content is not literally 'must have' in the sense that distributors cannot effectively compete without it. The evidence showed that distributors have successfully operated, and continue to operate, without the Turner networks or similar programming." Id. at 202. 
The district court decision also did not address whether AT\&T could offset blackout costs with increasing revenues from other market segments this highly diversified company serves. For example, AT\&T could benefit from migration to its broadband wired and wireless services by subscribers of both unaffiliated MVPDs and even its own satellite and terrestrial options. AT\&T would not lose much revenue if a DirecTV or U-verse subscriber cut off service but maintained or added AT\&T wireless or wired broadband service for accessing Hulu or YouTube TV. Additionally, AT\&T can raise its broadband and MVPD subscription rates, particularly for must-see content on channels such as HBO and CNN; exploit flexibility to favor its content through zero rating; ${ }^{67}$ and use other tactics designed to make it more expensive or inconvenient for consumers to access video content from an AT\&T competitor. In addition, AT\&T can provide one-stop shopping opportunities through its capacity as a vertically integrated enterprise that creates and packages content for delivery via its satellite, fiber optic cable, and wireless networks. The company has unfettered opportunities to offer subscriptions that bundle video content, telephone service, and Internet broadband access.

Critics of the district court decision see bias in Judge Leon's decision, which embraced nearly all testimony presented by AT\&T and its expert witnesses and rejected nearly all of that presented by the Justice Department and its experts. ${ }^{68}$ Additionally, the decision exclusively addressed the potential for AT\&T to exploit its ownership of desirable video content as a means to extort higher prices (therein bolstering AT\&T to the detriment of competing content providers and consumers), while ignoring the other harms posed by the merger. The court concentrated on the potential for AT\&T to coerce unaffiliated MVPDs to pay more for Time Warner video. ${ }^{69}$ It considered implausible all scenarios presented by the Justice Department, including the threat of more blackouts. ${ }^{70}$

67. "Zero rating" provides subscribers with cost-saving opportunities where an ISP offers to not debit a subscriber's monthly data allotment when she downloads content originating from specific sources. See Rob Frieden, Freedom To Discriminate: Assessing the Lawfulness and Utility of Biased Broadband Networks, 20 VAND. J. ENT. \& TeCH. L. 655 (2018); Ellen P. Goodman, Zero-Rating Broadband Data: Equality and Free Speech at the Network's Other Edge, 15 COLO. TECH. L.J. 63, 64 (2016).

68. See Steven C. Salop, The AT\&T/Time Warner Merger: How Judge Leon Garbled Professor Nash, 6 J. Antitrust ENFORCEMENT 459, 466 (2018). A "credulous and determined judge, prepared to believe whatever businesspeople told him, found that a deal as extraordinary as AT\&T/Time Warner essentially could not cause harm. That result hinged on one specific, fundamental finding of fact-Judge Leon's view that literal 'blackouts' in TV negotiations won't happen. Even if that claim were true, it turns out to be irrelevant to the government's theory of harm." Chris Sagers, The Worst Opinion in Living Memory: AT\&T/Time Warner and America's Broken Merger Laws (Mar. 4, 2019), https://perma.cc/VWS6-WEUR.

69. The Justice Department argued that "by combining Time Warner's programming and DirecTV's distribution, the merger would give Time Warner increased bargaining leverage in negotiations with rival distributors, leading to higher, supracompetitive prices for millions of consumers." $A T \& T I I$, 916 F.3d at 1035.

70. As the court put it:

The Government's primary theory of harm to competition focuses on the challenged merger's integration of Turner's important video content — content that includes, among other things, the networks CNN, TNT, and TBS - with AT\&T's video distributors, U-verse and DirecTV. Specifically, the Government contends that, should the challenged merger proceed, Turner's 
Judge Leon assumed that no MVPD, including AT\&T, could ever accrue a competitive advantage using a protracted blackout, based on his determination that blackouts always have short durations because of the mutual and compelling incentives for all parties to avoid blackouts in just about any circumstance. ${ }^{71}$ The judge speculated that even though MVPDs regularly agree to more generous compensation agreements, MVPD competitors of AT\&T would not suffer financially if the company did not have a competitive inventory of must-see Time Warner content. ${ }^{72}$

Judge Leon's decision appears to discount even the possibility that AT\&T could accrue strategic and financial advantages by triggering blackouts in its capacity as an MVPD in order to reduce or eliminate increases in its still substantial program access costs, particularly for retransmission rights to local broadcast television stations. ${ }^{73}$ Under this scenario, AT\&T would risk churn by its MVPD subscribers as they grew frustrated by channel blackouts. However, the company might consider this financial risk readily offset by savings in retransmission costs, increased broadband subscription revenues, upward shifts in service tier subscriptions by existing customers, and possibly greater flexibility in deciding to which service tiers and video-on-demand options AT\&T could offer the most desired content. ${ }^{74}$

In completely rejecting the government's attempts to prove that AT\&T's merger with Time Warner would substantially lessen competition, the district court decision

relationship with AT\&T will enable Turner to extract greater prices from AT\&T's rival distributors for its 'must-have' content than it could without the merger. ... I conclude that the Government has failed to clear the first hurdle of showing that the proposed merger is likely to increase Turner's bargaining leverage in affiliate negotiations; I thus need not consider the separate legal question of whether any effects associated with the Government's increased-leverage theory would result in a substantial lessening of competition for purposes of the Clayton Act's prohibitions.

AT\&T I, 310 F. Supp. 3d at 198-99.

71. Id. at 172 ("Because blackouts are almost always negative events for both programmers and distributors . . . bargains between programmers and distributors are almost always struck in order to avoid long-term blackouts.").

72. Id. at 202 ("I therefore give little credit to blanket statements by third-party competitor witnesses indicating that the entire 'viability of [their] video model' could depend on whether they offer Turner programming," usually considered one of Time Warner's most desirable content.).

73. Judge Leon recognized that video programmers or MVPDs might trigger the onset of a blackout:

Blackouts have negative consequences for programmers and distributors alike. On the programming side, a blackout causes a programmer to suffer immediate (and unrecoverable) losses of both advertising and affiliate fee revenue.... On the distributor side, a blackout may lead a distributor to lose subscribers or may prevent the distributor from attracting new subscribers.

Id. at 172. However, the judge never addressed MVPD-initiated blackouts and whether AT\&T might have increased incentives to initiate possibly long-term blackouts.

74. In July 2019, AT\&T and CBS could not reach closure on a revised retransmission consent agreement, resulting in a blackout. See Edmund Lee, CBS Is Blacked Out for 6.5 Million AT\&T Customers. Here's Why, N.Y. Times (July 20, 2019), https://perma.cc/V99K-7QCB ("CBS had been paid an average of a little over $\$ 2$ for each AT\&T subscriber every month, and it is now seeking a fee in the range of $\$ 3$, three people familiar with the matter said.... In addition to a smaller fee increase, AT\&T is pushing for the ability to sell CBS's streaming service as a separate option, which could give it more flexibility and lower costs by potentially removing the channel from its basic bundle."). 
reiterated the existing, conventional view that vertical mergers do not likely harm competition because the combining parties did not compete with each other in the first place. ${ }^{75}$ The decision rejected all of the Department of Justice's ("DOJ") arguments that the merger would enable the combined company to charge rivalsand, in turn, consumers - higher prices than those a standalone Time Warner could have imposed for access to its video content. It also rejected the contention that AT\&T would attempt to stifle competition generated by so-called virtual MVPDs, such as Amazon, Apple, and Netflix, which offer video content via OTT broadband links, or that it would prevent rivals from using $\mathrm{HBO}$ as a promotional tool to attract and retain subscribers. ${ }^{76}$

In rejecting the proposition that AT\&T would have more opportunities to extract higher payments from unaffiliated MVPDs in exchange for access to must-see content, Judge Leon concluded "that the Government has failed to clear the first hurdle of showing that the proposed merger is likely to increase Turner's bargaining leverage [over access to CNN and other most-desired content] in affiliate negotiations." 77 Therefore, the court did not even have to consider whether and how the merger would result in a substantial lessening of competition, the evaluative criterion required by Section 7 of the Clayton Act. ${ }^{78}$

The decision emphasized the assumption that content providers will not use blackouts to gain a negotiation advantage, because they cannot possibly profit from such a strategy. Judge Leon failed to recognize both that changes in the customary course of content carriage disputes are already under way due to market entry by OTT subscription services, and the likelihood that AT\&T would develop new strategies after acquiring Time Warner. For example, AT\&T has already decided to forego the substantial, ongoing, and reliable content revenue streams it could generate by leasing access to Time Warner content to OTT ventures like Netflix, and instead is offering exclusive access via its online services. ${ }^{79}$

75. AT\&TI,310 F. Supp. 3d at 192 ("[T]he proposed transaction between AT\&T and Time Warner is a vertical merger-i.e., one that involves 'firms that do not operate in the same market' and thus "produce[s] no immediate change in the level of concentration in any relevant market." (citations omitted)). For background on the potential for harm to consumers and competition from vertical mergers, see Steven C. Salop, Invigorating Vertical Merger Enforcement, 127 YALE L.J. 1962 (2018); Lina M. Khan, Amazon's Antitrust Paradox, 126 YALE L.J. 710 (2017); James Langenfeld, Non-Horizontal Merger Guidelines in the United States and the European Commission: Time for the United States To Catch Up?, 16 Geo. MASON L. REv. 851 (2009).

76. AT\&T I, 310 F. Supp. 3d. at 245-46, 250-51 ("I conclude that the Government has failed to meet its burden on its claims arising from AT\&T's asserted potential to unilaterally harm virtual MVPDs through its post-merger control of Turner content. ... First, the Government has failed to show that the merged entity would have any incentive to foreclose rivals' access to HBO-based promotions. This is because the Government's promotion-withholding theory conflicts with HBO's business model, which remains 'heavily dependent' on promotion by distributors... Second, the Government fails to establish that HBO promotions are so valuable that withholding or restricting them will drive customers to AT\&T. Put differently, the Government has failed to show that the marketplace substitutes for HBO are 'inferior, inadequate, or more costly."').

77. Id. at 199 .

78. 15 U.S.C. $\S 18(2012)$.

79. As one commentator has written: 
A quite plausible reason for AT\&T to tolerate longer blackouts, post-merger, stems from the greater likelihood that it would have steady or increasing revenues from the wired and wireless broadband Internet access it provides consumers who subscribe to OTT streaming services. ${ }^{80}$ Additionally, one of AT\&T's several MVPD options might still offer content blacked out on another AT\&T MVPD; for example, content blacked out by DirecTV could remain available in some or all localities with access to AT\&T's U-verse video service.

Judge Leon declined to consider whether a venture like AT\&T, which operates in multidimensional markets, would have more incentives to "hang tough" and tolerate longer blackouts in its combined capacity as both programmer and MVPD. ${ }^{81}$ Some of the customers of an AT\&T MVPD competitor would migrate to an AT\&T MVPD still having an active retransmission agreement option during a blackout of AT\&T's most desired channels on the competitor's service. Alternatively, during a blackout these churning consumers could opt to subscribe to an AT\&T broadband service as a supplement to what AT\&T and its competitors offer, or as a replacement.

The D.C. Circuit Court of Appeals affirmed the district court's decision, despite having identified a significant — and arguably serious - mistake in its analysis. ${ }^{82}$ The appellate court held that the lower court did not clearly err in finding that the government failed to show the proposed merger would violate the Clayton Act. It accepted the lower court's unquantified assessment that the video marketplace operated with enough competition to counteract any increased bargaining leverage

Taking popular shows from services like Netflix and Hulu makes sense for AT\&T as it tries to convince consumers to subscribe to the platform. It's also a significant strike against rival companies. Some of Netflix's most popular shows are WarnerMedia properties, including Friends, which Netflix executives paid \$100 million to stream exclusively through 2019 . That number may seem obscene, but Friends is one of the most-watched shows on Netflix, according to data from numerous analytics firms.

Julia Alexander, AT\&T Will Pull Popular Shows Like Friends from Streaming Competitors, Says CEO, VERGE (May 14, 2019), https://perma.cc/A85Q-AMZ8.

80. See John Eggerton, AT\&T: Locast is an Option if There is CBS Blackout, MulTICHANNEL NEws (July 19, 2019), https://perma.cc/ZKE2-B2Q7 ("AT\&T was talking tough Friday as a retrans blackout with CBS loomed, including steering subs to the Locast over-the-top TV station streaming service as one option to preserve access to TV station signals if there is an extended outage.").

81. One can divide the video content marketplace into six discrete segments: "the market for programmer acquisition of content; the market for programmer access to distribution; the market for viewer access to distribution; the market for advertiser access to programming; the market for advertiser access to distributors; and the market for advertiser access to viewers." Henry H. Perritt, Jr., Keeping the Internet Invisible: Television Takes Over, 21 J. TECH. L. \& POL’Y 121, 159 (2017).

82. In the Court of Appeals' language:

It is true that the district court misstated that the government had not proven that any price increases would "outweigh the conceded $\$ 350$ million in annual cost saving to AT\&T's customers." Professor Shapiro testified that the merger would result in $\$ 352$ million cost savings to AT\&T and that not all those savings would be passed on to consumers. The $\$ 352$ million, therefore, was not cost savings to consumers but to AT\&T. But the district court did not weigh increased prices for consumers against cost savings for consumers, and instead found that the government had not shown at the first level that the merger was likely to lead to any price increases for consumers because of the failure to show that costs for rival MVPDs would increase as a result of Turner Broadcasting's increased leverage in affiliate negotiations after the merger.

United States v. AT\&T, Inc. (AT\&T II), 916 F.3d 1029, 1046-47 (D.C. Cir. 2019). 
AT\&T would have after acquiring Time Warner. Perhaps most important of all, the appellate court placed great emphasis on AT\&T's offer, in its capacity as a content programmer, to seek "baseball style" arbitration of its content access disputes with MVPDs over the next seven years, and on the existence of contracts that locked in content carriage rates until 2021. ${ }^{83}$ Baseball style arbitration maintains the status quo during negotiations, thereby foreclosing blackouts of AT\&T-owned content networks, and long-term content carriage contracts prevent near-term rate increases.

The appellate court also glossed over Judge Leon's faulty assumption that AT\&T would pass through to subscribers all of its video content savings accruing from owning Time Warner content, rather than having to pay this previously unaffiliated company a marked-up price that includes a profit margin. The court accepted the accuracy of an estimated $\$ 352$ million in savings, despite having expressed skepticism about all other forecasts of higher costs to consumers predicted by DOJ's expert witnesses. ${ }^{84}$ After receiving approval to acquire Time Warner, AT\&T has increased rates several times. ${ }^{85}$ The appellate court did note that Judge Leon incorrectly assumed that all of AT\&T's estimated $\$ 352$ million in video programming cost savings would flow to subscribers, but dismissed that error as "harmless" because the court agreed with the lower court that DOJ had failed to prove that AT\&T could raise customer rates at all, despite ample available evidence that MVPDs annually increase subscription rates well above general inflation measures. $^{86}$

83. Id. at 1035 (“As mentioned, Turner Broadcasting 'irrevocably offer[ed]' approximately 1,000 distributors agreements to engage in baseball style arbitration in the event the parties fail to reach a renewal agreement, and the offered agreement guarantees no blackout of Turner Broadcasting content once arbitration is invoked. AT\&T's counsel represented the no-blackout commitment is 'legally enforceable.' ... Consequently, the government's challenges to the district court's treatment of its economic theories becomes largely irrelevant, at least during the seven-year period.").

84. Id. at 1046 ("Neither Professor Shapiro's opinion testimony nor his quantitative model considered the effect of the post-litigation offer of arbitration agreements, something he acknowledged would require a new model. And the video programming and distribution industry had experienced 'everincreasing competitiveness' in recent years. [citation] Taken together, the government's clear-error contention therefore fails.").

85. See Todd Shields, David McLaughlin \& Scott Moritz, DirecTV to Hike Prices After Owner AT\&T Promised Cheaper Bills, BloOMBERG (Mar. 14, 2019), https://perma.cc/Q3VL-ST3H (“AT\&T Inc. is hiking prices on its pay TV services for the second time since January, even after telling a judge during the U.S. antitrust trial last year that prices would go down if it was allowed to buy Time Warner Inc.").

\section{Specifically, the court found that:}

[t]he $\$ 352$ million, therefore, was not cost savings to consumers but to AT\&T. But the district court did not weigh increased prices for consumers against cost savings for consumers, and instead found that the government had not shown at the first level that the merger was likely to lead to any price increases for consumers because of the failure to show that costs for rival MVPDs would increase as a result of Turner Broadcasting's increased leverage in affiliate negotiations after the merger .... Consequently, because the government failed to meet its burden of proof under its increased leverage theory at the first level, the error regarding cost savings was harmless error . . . .

$A T \& T$ II, 916 F.3d at 1046-47. On customer rate increases, see, for example, Implementation of Section 3 of the Cable Television Consumer Prot. And Competition Act of 1992, 33 FCC Rcd. 1268, 1270 (2018) (reporting an average cable television rate increase of $4.4 \%$ over the 12 months ending January 1, 2016, compared to a $1.4 \%$ increase in the Consumer Price Index during the same time period). 
After AT\&T received approval to acquire Time Warner, many of the DOJ's predicted harms to consumers and competition have occurred. Since the acquisition, AT\&T has raised DirecTV, U-verse, and HBO subscription rates significantly, despite unprecedented declines in subscribership. ${ }^{87}$ The company also has marketed access to $\mathrm{HBO}$ as an inducement for customers to bundle two or more AT\&T services, even as it makes it more difficult for competing MVPDs to offer similar bundling opportunities. ${ }^{88}$

Additionally, the company has shown a greater tolerance for geographically widespread and longer lasting blackouts of local broadcast television channels. ${ }^{89}$ For example, in July 2019, AT\&T stopped distributing all CBS-owned and -operated broadcast stations and two CBS cable networks, as well as the 120 broadcast stations owned by Nexstar. $^{90}$ After blackouts lasting up to fifty-seven days, the parties reached a new confidential agreement. ${ }^{91}$

87. See, e.g., Todd Spangler, AT\&T Confirms DirecTV Now Price Hikes, Launches New 'Slimmer' Bundles With HBO That Omit Many Cable Channels, VARIETY (Mar. 13, 2019), https://perma.cc/8C8HMVLP; David Lazarus, AT\&T's Promise of Better Pay-TV Prices and Service Is 'Bordering on the Absurd, ' L.A. TIMES (Aug. 6, 2019), https://perma.cc/E8UL-PQ5X; Karl Bode, AT\&T Jacks Up TV Prices Again After Merger, Despite Promising That Wouldn't Happen, VICE (Mar. 12, 2019), https://perma.cc/H79Z-XT5G; Jon Brodkin, AT\&T To Lose 1.1 Million TV Subscribers as DirecTV Continues Nosedive, ARS TECHNICA (Sept. 12, 2019), https://perma.cc/48DF-ST9A.

88. Compare Judge Leon's dismissal of this possibility:

The basic idea, the Government tells us, is that rival distributors' use of HBO in promotions will tend to draw potential customers to those MVPDs and away from AT\&T, thereby giving AT\&T reason to withhold or restrict its consent to use HBO in marketing, discounts, and bundles . . . . At the risk of stating the obvious, this is a gossamer thin claim.

United States v. AT\&T, Inc. (AT\&T I), 310 F. Supp. 3d 161, 250 (D.D.C. 2018). See also Ashley Rodriguez, AT\&T's Streaming-TV Service Is Now Forcing You To Buy HBO, QUARTZ (Mar. 13, 2019), https://perma.cc/AD7D-5YST.

89. See Ben Munson, AT\&T Declines Deal to Keep Local Channels on DirecTV, U-verse, Nexstar Claims, FiERCE VIDEO (July 8, 2019), https://perma.cc/3V3T-Z22P (“AT\&T's pay TV services[,] including DirecTV, DirecTV Now and U-verse, lost more than 120 stations available to consumers and viewers in 97 markets across the United States. The blackouts came after AT\&T and Nexstar failed to reach a new retransmission consent agreement for the channels.").

90. One commentator described the July 2019 blackout as follows:

The carriage contract between the CBS stations and AT\&T-owned satellite giant DirecTV, DirecTV Now and U-verse cable systems officially expired Friday [July 19, 2019] at 11 PM PT. Affected markets include New York, LA, Chicago, Philadelphia, Dallas, San Francisco, Boston, Atlanta, Tampa, Seattle, Detroit, Minneapolis, Miami, Denver, Sacramento, Pittsburgh and Baltimore and 117 CBS stations and affiliates on DirecTV Now. In addition, CBS Sports Network has gone dark nationally from DirecTV and DirecTV Now, and Smithsonian Channel is down on DirecTV.

Dade Hayes, CBS Stations Go Dark on DirecTV, U-Verse in AT\&T Contract Dispute—Update, DEADLINE (July 20, 2019), https://perma.cc/WA6Q-XT23. See also Linus Chua, AT\&T, Nexstar in Dispute After 120 Stations Black Out on Holiday, BLOOMBERG (July 4, 2019), https://perma.cc/3E73-9KBF.

91. See Nexstar and AT\&T Statement on New Distribution Agreement, BUS. WIRE (Aug. 29, 2019), https://perma.cc/M738-HBHS. 


\section{TENTATIVE CONCLUSIONS}

This Article has identified several factors that contribute to an environment where vertically and horizontally integrated ventures, such as AT\&T and Comcast, have greater incentives to tolerate - if not provoke - a blackout, leverage access to mustsee content they own, harm competition, and raise consumer costs. MVPDs cannot assume that they can simply raise subscription rates to absorb higher programming costs, and accordingly are less likely to maintain the status quo of accepting more expensive terms and conditions for the carriage of broadcast television and pay television networks. Significant, measurable, and growing subscriber churn provides empirical evidence that not all MVPD subscribers will tolerate rate increases that perennially exceed general measures of inflation.

The onset of substantially more blackouts, particularly those triggered by AT\&T's refusal to pay higher broadcast television retransmission consent rates, points to fundamental mistakes and assumptions underlying the judicial review of the company's acquisition of Time Warner. Both court decisions made micro-level assumptions about individual company behavior and macro-level assumptions about how the video marketplace works that do not jibe with current and evolving conditions. Additionally, the decisions further bolster the conventional wisdom that vertical integration through mergers and acquisitions will likely generate no harms to competition or consumers, and might even have a positive impact. Firms that pursue both vertical and horizontal acquisitions respond to technological and market convergence in ways that further reduce the number of firms providing one-stopshop access to both proliferating content and access options.

One cannot summarily conclude that dominant firms, like AT\&T and Comcast, will refrain from engaging in anticompetitive practices made available by their presence in nearly all market segments in the information, communications, and entertainment ecosystem. These firms have both the incentive and ability to execute strategies that exploit their ability to trigger blackouts, in their capacities as both program suppliers and MVPDs. For example, AT\&T can offer bundles of services that obscure individual costs, including an HBO subscription. Additionally, the company can exploit the FCC's disinterest in investigating whether pricing decisions, such as zero rating, confer an unfair competitive advantage accrued by raising the cost of access to must-see content, like HBO, for both unaffiliated MVPDs and customers unwilling to acquire a bundle of AT\&T wireless cellphone service, video programming, and broadband access. ${ }^{92}$

AT\&T's newfound interest in triggering more and longer blackouts demonstrates that the MVPDs do not have a single business plan and identical marketplace behavior. These companies have quite different strategies, based in part on whether they are vertically integrated (through ownership of programming) and horizontally integrated (through ownership of alternative video programming delivery technologies).

92. See Jon Brodkin, AT\&T Is Doing Exactly What It Told Congress It Wouldn't Do with Time Warner, ARS TECHNICA (Feb. 2, 2020), https://perma.cc/B9PA-EY7Y. 
AT\&T's particularly active blackout strategy since its acquisition of Time Warner warrants close scrutiny and analysis. The fact that AT\&T has become much more aggressive in negotiations and its apparent willingness to tolerate more blackouts provide support for arguments made by the Justice Department in its opposition to the company's acquisition of Time Warner. Two reviewing courts largely dismissed every argument the government made about bolstered incentives for AT\&T to demand higher rates from competing MVPDs for access to its expanded inventory of must-see content, as well as a contemporaneous strategy of triggering blackouts in its capacity as an MVPD.

In both scenarios, AT\&T may benefit from video subscriber migration triggered by a blackout. If an MVPD cannot deliver must-see content owned by AT\&T, some subscribers might defect to AT\&T, in its capacity as a competing satellite and terrestrial MVPD still offering the preferred content, while others might migrate to one of AT\&T's wired and wireless broadband access options to secure alternative, but available, OTT programming, including local broadcast television stations available from Hulu and YouTube TV. AT\&T could benefit from cord-cutting subscribers of a competing MVPD, because some might become AT\&T broadband subscribers. Cord shavers might like AT\&T's discounted access to video content, bundled with a wired or wireless broadband subscription. Cord nevers probably have limited appetite for monthly video content subscriptions, but they might consider an inexpensive, skinny bundle of video content offered in conjunction with their AT\&T wireless service subscription and "free" HBO access.

AT\&T appears to have devised and executed a sophisticated, multi-faceted strategy to offset the financial harm and customer anger from blackouts. The company now aggressively seeks to reduce increases in programming costs, in its capacity as an MVPD, apparently confident that it can offset at least some of the customer churn during a blackout with consumer migration to one or more of its MVPD and broadband access services. Bear in mind that with the near-total elimination of broadband regulatory oversight, ${ }^{93}$ the company can create attractive inducements, such as free, discounted and zero-rated wireless access to HBO and the content available from DirecTV, including access to all professional football game telecasts. ${ }^{94}$

The future video marketplace appears more likely to have blackouts, because ventures, like AT\&T, can anticipate upside competitive and financial benefits. Even if we accept the view that the company cannot act on its incentives to trigger blackouts as a video programmer, the company offers several MVPD options where

93. Restoring Internet Freedom, 33 FCC Rcd. 311 (2018), aff'd in part sub nom. Mozilla Corp. v. FCC, 940 F.3d 1 (D.C. Cir. 2019) (affirming the reclassification of broadband access as an information service and the removal of specific safeguards, but reversing on preemption of state regulation and remanding for impact assessments on public safety, pole attachment, and universal service funding policy). AT\&T only needs to meet transparency requirements by disclosing its practices that, for example, prioritize, throttle, or zero-rate specific types of traffic.

94. AT\&T has offered service bundles that include its NFL Sunday Ticket access to NFL telecasts and HBO. See NFL, AT\&T DIRECTV, https://www.directv.com/sports/nfl (last visited Apr. 18, 2020). See also Mark Conrad, A New Game in Town: Disseminating Sports Content in a Net Neutrality-Less Era-The Potential Implications for the Post-Broadcasting World, 29 J. LEGAL ASPECTS SPORT 1 (2019). 
blackouts can have a revenue neutral, or even positive impact. Of course, an MVPD no longer offering must-see content creates even more incentives for consumer churn. But few companies can reduce or eliminate revenue harm with possible consumer migration from one AT\&T MVPD to another, or to an alternative OTT option, accessed via the wired and wireless broadband links the company offers. AT\&T and other fully integrated firms can and should exploit economies of scale and scope, but without effective regulatory oversight and antitrust enforcement significant and readily identifiable harms to competition and consumers can occur. 